\title{
Physical education curriculum model: Can FEM and SEM create participation in physical activity and enjoyment?
}

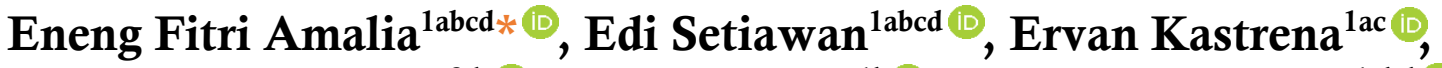

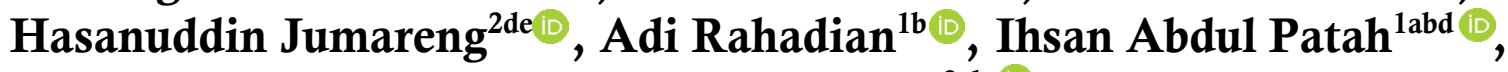 \\ Ruslan Abdul Gani ${ }^{3 a b}$ (1) \\ Universitas Suryakancana, Indonesia ${ }^{1}$ \\ Universitas Halu Oleo, Indonesia ${ }^{2}$ \\ Universitas Singaperbangsa Karawang, Indonesia ${ }^{3}$
}

Received: 08 May 2021; Accepted 17 July 2021; Published 27 August 2021

Ed 2021; 6(3): 286-295

\begin{abstract}
The low participation in physical activity and enjoyment among students is the main problem factor in this study. The purpose of this study is to try to increase participation in physical activity and student enjoyment through FEM and SEM which are integrated into physical education learning. This study is using quantitative research with experimental methods. 30 students Departement of Physical Education, Health, and Reacreation from Universitas Suryakancana are willing to be the subjects in this research. The research instrument uses IPAQ and EPESC. Data analysis uses IBM SPSS version 25 with a significance level of 0.05 . The results of this study find that both of FEM and SEM have a significant impact on increasing students' participation in physical activity and enjoyment. This study confirms that FEM and SEM are pedagogical tools that lecturers can use to change participation in students' physical activity and enjoyment from low to high.
\end{abstract}

Keywords: Fitness education models; sports education model; participation in physical activity; enjoyment

https://doi.org/10.25299/sportarea.2021.vol6(3).6851

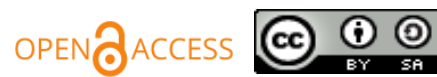

Copyright @ 2021 Eneng Fitri Amalia, Edi Setiawan, Ervan Kastrena, Hasanuddin Jumareng, Adi Rahadian, Ihsan Abdul Patah, Ruslan Abdul Gani

Corresponding Author: Eneng Fitri Amalia, Department of Physical Education Health and Recreation, Faculty of Teacher Training and Education, Universitas Suryakancana, Cianjur, Jawa Barat, Indonesia

Email: fitriamalia@unsur.ac.id

How to Cite: Amalia, E. F., Setiawan, E., Kastrena, E., Jumareng, H., Rahadian, A., Patah, I. A., \& Gani, R. A. (2021). Physical education curriculum model: Can FEM and SEM create participation in physical activity and enjoyment?. Journal Sport Area, 6(3), 286-295. https://doi.org/10.25299/sportarea.2021.vol6(3).6851

Authors' Contribution: a - Study Design; b - Data Collection; c - Statistical Analysis; d - Manuscript Preparation; e - Funds Collection

\section{INTRODUCTION}

The progress of a nation in the $21^{\text {st }}$ century is highly dependent on the quality of human resources produced through a long process of educational activity (Rakhmawati 2017). Education will be carried out well if it is supported by a curriculum unit that has been prepared in such a way by a country. The Indonesian government currently has implemented the 2013 curriculum which focuses on character building which includes: spiritual attitudes, social attitudes, knowledge, and skills (Mustafa, 2020). The curriculum is basically an important tool in the educational process. It means that education and curriculum are interrelated with one another. If the curriculum can run effectively, the learning process and the results 
of learning will also get optimal results (Walton-Fisette \& Sutherland, 2018). Implementation of a curriculum model serves to make learning procedures more complex and diverse (Thorburn, 2015), so that later from the process it can create quality generations of people who are able to compete at the national and international levels. Basically, the curriculum is dynamic, so it must continue to be evaluated, changed, and developed according to the needs of the times (Mustafa, 2020). According to Mustafa (2021) a curriculum has an important role to formulate the goals of the learning process in each country (Innerd, Azevedo, \& Batterham, 2019), so that from the use of the curriculum model it will be able to develop the potential of students as a whole related to the cognitive, psychomotor, social, and affective domains so that they are much more improved than before (Setiawan, Patah, Jumareng, \& Kastrena, 2020). An important factor that must be considered and developed in students is participation in physical activity and pleasure.

Participation in physical activity is the involvement of a person to participate in activities that leads to the occurrence of body movements produced by skeletal muscles that require energy expenditure (Prasetyo \& Winarno, 2017). With high participation in physical activity, students will carry out learning activities more optimally (Silva, Chaput, \& Tremblay, 2019). On the other hand, if students have a low level of participation in physical activity, the learning objectives will not be achieved. The results of previous studies showed that the percentage of participation in physical activity of students who took physical education every day decreased from $42 \%$ to $28 \%$ (El-Sherif, 2014). Recent data reported that there was a decrease in the level of participation in adolescent physical activity by $60.0 \%$ to $17.7 \%$ (Xiang et al., 2020). Similar to what happened in Indonesia, research results report that student movement activities are reduced in the current era (Ashadi, Andriana \& Pramono., 2020; Nugraha et al., 2020). This data is one of the evidences that the level of participation in physical activity is still low, especially at the student level.

Another aspect that is also in the spotlight and a factor that must be improved is the enjoyment of the students themselves. Enjoyment is a feeling of happiness, pleasure, or enjoyment in a person when following a lesson that has been done. According to Lohbeck, Tietjens, and Bund (2016) pleasure occurs when someone thinks that an activity is fun. Fun is one element that is expected to be created when the learning process carried out by students is not boring. Most previous studies have shown that pleasure is a key factor that positively triggers the emergence of motivation for further involvement in the physical education learning process (Dudley, Okely, Pearson, Caputi, \& Cotton, 2013; Bonavolontà et al., 2020). However, evidence shows that there is a decrease in enjoyment when doing sports (Grasten, Timo, Jarmo, Anthony, \& Sami, 2012), especially during a pandemic. Data reports that people's enjoyment of sports is reduced, because they often feel anxious, afraid when doing sports in the COVID-19 era (Elliott, 2021). Given these problems, there are two curriculum models that are estimated to have an effect on developing participation in physical activity and student enjoyment, namely Fitness Education Models (FEM).

FEM as a curriculum designed exclusively focuses on education through physical activities that aims to improve fitness related to cardiovascular endurance, muscle strength and endurance, flexibility, speed, agility, coordination, and balance (Shimon, Johnson, Moorecroft, \& Bell, 2013). FEM is a subcomponent of the physical education program, with a focus on assisting students in acquiring a high level of knowledge and understanding related to fitness and physical activity (Fu, Gao, Hannon, Shultz, Newton, \& Sibthorp, 2013).

Another model that is thought to have the same power to increase participation in physical activity and enjoyment is the Sport Education Model (SEM). This model is explicitly designed to offer a professional sports experience for students in the context of physical education (Deenihan \& Macphail, 2013). SEM becomes a learning curriculum that allows students to have more time to play and practice to improve skills, so that with the use of SEM, students feel comfortable and they do not feel bored in the learning process (Setiawan et al., 2020). The popularity of SEM is currently increasing, as evidenced by many countries, such as Australia, China, and Taiwan, which implement the SEM curriculum at school and at the university level (Kirk, 2013; Bessa, Hastie, Rosado, \& Mesquita, 2021). The characteristics of the SEM curriculum require students to choose their respective roles, for example students can choose the role of coach, player, referee, manager, or medical team, where in the learning process they must be able to take responsibility for carrying out these roles (Setiawan et al., 2020). With such a learning system, students will focus more on 
learning their respective roles in SEM. The purpose of implementing SEM is to educate students in developing good skills, values, and attitudes in sports, so that they can enjoy active participation in sports activities (Hasyim et al., 2020). From the long-term learning process, the ultimate goal to be achieved through the application of the SEM curriculum is to be able to make students into competent, literate, and enthusiastic sportsmen. Most of the previous research on SEM focused on the competence and participation of students in playing (Araújo, Hastie, Lohse, Bessa, \& Mesquita, 2019), and students' motivation in participating in learning (Wallhead, Garn, \& Vidoni, 2014). The results of previous studies reported an increase in students' enthusiasm, participation, and interest in learning due to the application of SEM. Thus, it can be seen that this SEM curriculum model provides many positive benefits in aspects such as students' motivation to participate in physical activity, so that playing skills in a sport also develop (Farias, Valério, \& Mesquita, 2018).

All programs contain in the FEM and SEM curricula seek to create high participation in physical activity and the most important thing is to make students feel pleasure in exercising. Research result of Lee, Oh, Baek, and Kim, (2016) reported that the SEM curriculum makes students more active in learning physical education, even being able to make someone happy in doing all physical activities (Hastie \& Wallhead, 2016). Another study found that SEM is a widely used physical education curriculum model and has been associated with positive psychological outcomes among students, such as increased competence, affiliation, motivation (Gil-Arias et al., 2017), and enjoyment (Chu \& Zhang, 2018). However, research conducted by Iserbyt, Ward, and Martens (2016) found that SEM is not able to improve the psychomotor aspects related to students' basic swimming techniques. Inconsistent results in previous studies are an urgent problem that must be revealed immediately.

Although many previous studies have examined the curriculum related to FEM and SEM (Romar, Henriksson, Ketomäki, \& Hastie, 2016; Bessa et al., 2021), but there is no literature that tries to analyze the two curriculum models simultaneously. In addition, previous studies at the university level focused only on analyzing how a teacher applied this model to build teamwork and develop motivation (Deenihan \& MacPhail, 2017; Mooney, Moncrieff, \& Hickey, 2018), and no studies have been found that attempt to analyze how the two curricula between FEM and SEM can increase participation in physical activity and enjoyment of sports in university. This research has an impact on the development of science in the field of physical education curriculum, which can later be useful for lecturers and teachers in the learning process. The purpose of this study is to increase student participation in physical activity and enjoyment of sports using FEM and SEM.

\section{METHOD}

The type of research used is quantitative with the use of experimental methods. The experimental method is a study that deliberately gives the effect of one or more independent variables on the dependent variable. In this study, two independent variables are used, namely FEM and SEM, while the dependent variable used is participation in physical activity and pleasure.

\section{Subject}

The subjects used in this study are 30 students from the Department of Physical Education, Health and Recreation at Universitas Suryakancana, Cianjur. Subjects have characteristics that are 20-23 years old, weigh 60-70 kg, height ranges from 58-73, and they are male and female. Before the study began, all subjects were asked to make a statement of willingness to participate in all activities carried out in this study. The technique for selecting subjects used purposive sampling, namely the selection of subjects based on certain criteria, for example the subjects selected were male and female students who had low participation in physical activity and pleasure. To determine the level of participation in physical activity and students' enjoyment, the researchers conducted observations before conducting the pre-test. 


\section{Instrument}

Physical Activity. Instruments to measure students' physical activity can use "The International Physical Activity Questionnaire". In this case, the researcher will try to develop this instrument, so that it has 7 sub indicators as follows:

Table 1. Physical Activity Instrument Grid

Variables

Physical Activity

\section{Indicators}

1. In the last seven days, on how many days did you do strenuous physical activity for example lifting heavy objects or items, hoeing, aerobics or brisk cycling.

2. In the last seven days, on how many days did you do moderate physical activity such as lifting light objects or items, mopping floors, leisurely cycling, badminton.

3. In the last seven days, on how many days have you walked at least 3 kilos.

4. In the last seven days on how many days have you been physically active for at least 30 minutes.

5. In the last seven days, how many days did you sit and do nothing.

6. In the last seven days, how many days did you do physical activity, such as jogging, push up, sit up, and pull up.

7. In the last seven days, how many days did you do physical activity, such as playing basketball, futsal, or soccer.

After testing the instrument on level 1 students who have the same characteristics as the subjects in this study, the test uses bivariate correlation analysis (IBM SPSS 25), in order to obtain a validity value of 0.84 and a reliability value of 0.73 . The IPAQ consists of 7 questions consisting of strenuous physical activity, moderate physical activity, activities carried out in walking, and activities while relaxing or sitting. Physical activity carried out in the last 7 days. The total value of physical activity can be calculated by (metabolic equivalent) MET minutes/week. The activity duration data for the high category was multiplied by MET = 8. The moderate activity duration data was multiplied by MET $=3,3$. The low activity duration data was multiplied by MET $=4$. Then the results would be classified into moderate, low, and high physical activity criteria. The formula for calculating physical activity scores is Total MET-minutes/week = Low (4MET $\times$ minutes $\times$ day) + Medium (3.3MET $\times$ minutes $\times$ day) + High (8MET x min x day) (IPAQ, 2005). After getting the final result in MET minutes/week then classified into physical activity level.

Table 2. Classification of IPAQ Hasil Results

\begin{tabular}{clc}
\hline No & \multicolumn{1}{c}{ Metabolic Equavalent (MET-s) } & Category \\
\hline 1. & $>3000$ MET minutes/week & High physical activity \\
\hline 2. & $>600-3000$ MET minutes/week & Medium physical activity \\
\hline 3. & $<600$ MET minutes/week & Low physical activity
\end{tabular}

(IPAQ, 2005)

\section{Instrument of Enjoyment of Physical Education and Sport Scale}

Instruments to measure a person's level of pleasure can use the enjoyment scale in physical education and sports. According to Grasten et al., (2012) enjoyment in physical education and sports lessons is assessed using the Finlandia version of sub-indicator consists of 4 items, nevertheless the researcher will develop so that it has 16 sub indicators consisting of.

Table 3. Pleasure Instrument Grid

\begin{tabular}{|c|c|}
\hline Variables & Indicators \\
\hline \multirow{4}{*}{ Enjoyment } & 1. I really enjoy this. \\
\hline & 2. I feel bored. \\
\hline & 3. I don't like this. \\
\hline & 4. I find pleasure. \\
\hline
\end{tabular}




\begin{tabular}{|c|c|}
\hline Variables & Indicators \\
\hline \multirow{12}{*}{ Enjoyment } & 5. It's not fun at all. \\
\hline & 6. It gives me energy. \\
\hline & 7. This makes me sad. \\
\hline & 8. It's a lot of fun. \\
\hline & 9. The body feels fit. \\
\hline & 10. I found something from here. \\
\hline & 11. I am very excited. \\
\hline & 12. This frustrates me. \\
\hline & 13. It's not fun at all. \\
\hline & 14. It gives me a strong sense of success. \\
\hline & 15. It feels good. \\
\hline & 16. I think I'd better do something else. \\
\hline
\end{tabular}

The enjoyment of physical education and sport scale instruments based on previous studies have a level of reliability ( $\mathrm{r}=0.93$ to 0.89 ) and have construct validity (Gråstén, 2016). However, this instrument is retested using bivariate correlation analysis (IBM SPSS 25), so that the validity of this instrument is obtained at 0.88 and reliability 0.79 . For filling out this instrument uses a Likert scale consisting of (1) “Strongly Disagree" (STS), (2) Disagree (TS), (3) Neutral (N), (4) Agree (S), and (5) Strongly Agree.

\section{Research Procedure}

This research has obtained permission from the head of the Department of Physical Education, Health, and Recreation with letter number E 9/3-2021. This research is conducted in March 2021 with a total of 10 meetings and this research is carried out in the mini Physical Education, Health, and Reacreation field from 13.00-15.00 WIB and is carried out 3 times a week, namely on Monday, Wednesday, and Friday for treatment (FEM and SEM). In addition, in this study, researchers apply the standard COVID-19 protocol, namely checking the body temperature of research subjects and providing hand sanitizer.

\section{Data Analysis}

Data analysis is an important part of research. Data processing is carried out using the SPSS 25 software program. In this study, the first data analysis performed is looking for descriptive data (mean, SD), normality test (Shapiro-Wilk), and homogeneity (Levene-test) as well as analyzing the increase before and after administration of intervention using Independent t-test. The level of significance used is 0.05.

\section{RESULTS AND DISCUSSION}

Based on table 4, the results of the pre-test for the FEM group obtained a mean value of $=869.7$ and std. deviation $=8,643$. While the pre-test for the SEM group, the mean value $=778.4$ and std. deviation $=5779$. Then for the post-test FEM group the mean value $=988.2$ and std. deviation $=9.215$. While the post-test of the SEM group, the mean value $=899.6$ and std. deviation $=6.717$.

Table 4. Deskriptive of Data

\begin{tabular}{ccccc}
\hline Activity & Group & N & Mean & Std. Deviation \\
\hline \multirow{2}{*}{ Pre-Test } & FEM & 15 & 869.7 & 8.643 \\
& SEM & 15 & 778.4 & 5.779 \\
\hline \multirow{2}{*}{ Post-Test } & FEM & 15 & 988.2 & 9.215 \\
& SEM & 15 & 899.6 & 6.717 \\
\hline
\end{tabular}

Table 5. Normality of Data

\begin{tabular}{cccc}
\hline Activity & Group & N & P \\
\hline \multirow{2}{*}{ Pre-Test } & FEM & 15 & 0.120 \\
& SEM & 15 & 0.147 \\
\cline { 2 - 4 } Post-Test & FEM & 15 & 0.251 \\
\cline { 2 - 4 } & SEM & 15 & 0.224 \\
\hline
\end{tabular}


Based on table 5, the pre-test results for the FEM group $(\mathrm{P}-$ Value $=0.120)$ and the SEM group $(\mathrm{P}=$ $0.147)$. While the post-test results for the FEM group $(\mathrm{P}=0.251)$ and the SEM group $(\mathrm{P}=0.224)$. These data indicate that all variables are normally distributed.

Table 6. Homogeneity of Data

\begin{tabular}{ccccc}
\hline Activity & Group & N & P \\
\cline { 2 - 4 } Pre-Test & FEM & 15 & 0.227 \\
\cline { 2 - 4 } & SEM & 15 & 0.231 \\
\cline { 2 - 4 } Post-Test & FEM & 15 & 0.214 \\
\hline
\end{tabular}

Based on table 6, the pre-test results for the FEM group $(\mathrm{P}=0.227)$ and the SEM group $(\mathrm{P}=0.231)$. While the post-test results for the FEM group $(P=0.214)$ and the SEM group $(P=0.201)$. These data indicate that all variables have homogeneous variance.

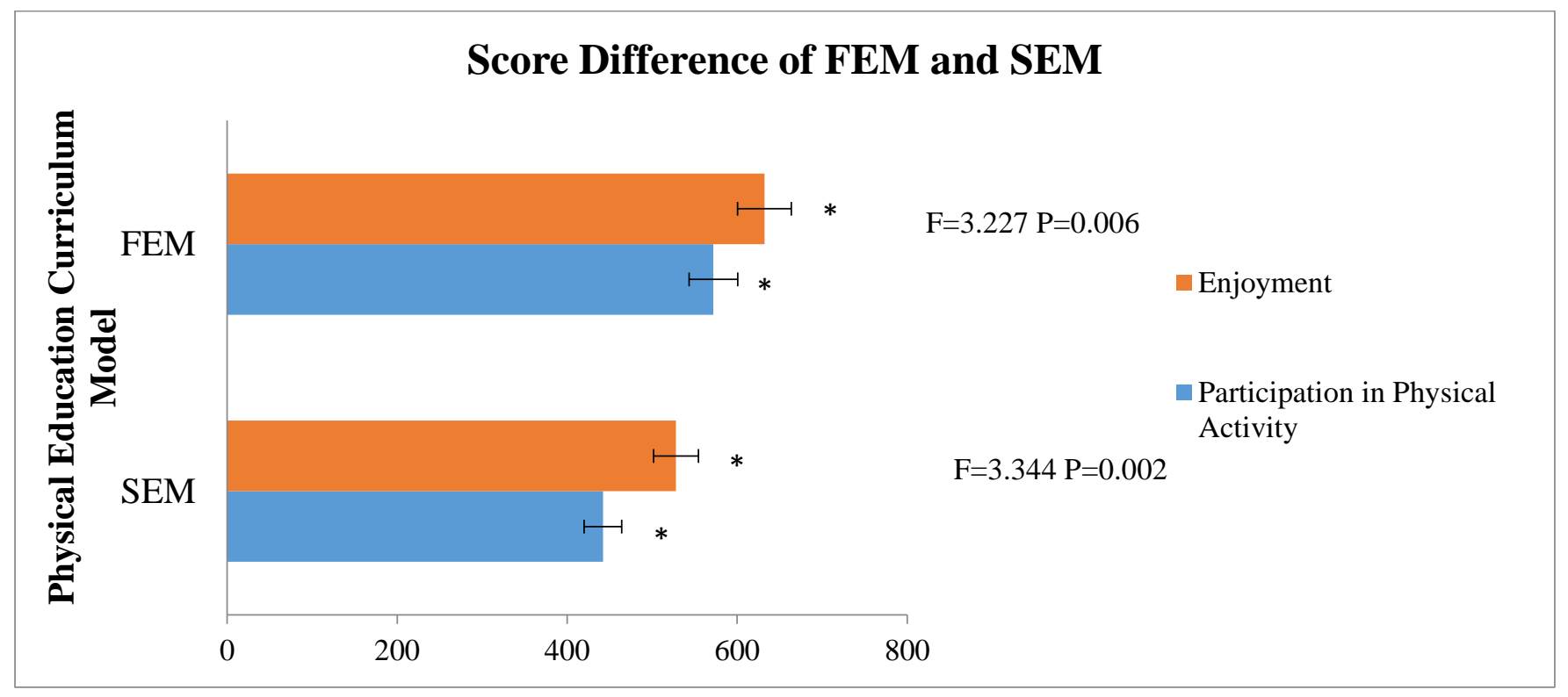

Figure 1. Graph of the Influence of FEM and SEM on Participation in Physical Activity and Pleasure

Based on Figure 1, the values for the FEM group $(\mathrm{F}=3.277 ; \mathrm{P}=0.006)$ and the SEM group $(\mathrm{F}=3.344 ; \mathrm{P}$ $=0.002)$ are obtained. Thus, it can be concluded that both physical education curriculum models between FEM and SEM have an impact on increasing participation in physical activity and students' enjoyment.

The purpose of this study is to increase participation in physical activity and enjoyment of students through FEM and SEM. The findings in this study indicate that FEM can positively increase participation in physical activity and students' enjoyment of being higher. This is due to the FEM curriculum model facilitates an interesting learning for students about a physical fitness lesson, for example students do tabata training, circuit training, and fartlek, so that through these activities trigger participation in much higher physical activities and students become more active and more fun when exercising. The results of this study are in line with previous studies which reported that FEM is a special model for increasing active participation in physical activities and fitness (Ward et al., 2017). In addition, the FEM curriculum is believed to foster students' enjoyment in physical activity (Shimon et al., 2013; Fu et al., 2013).

Similar to the FEM curriculum, the SEM curriculum model is found to have its own effect that can be obtained. At the beginning of SEM learning, students are given an understanding of the purpose of SEM learning which leads to education to create students with skills in a sport (Wallhead, Garn, \& Vidoni, 2013; Perlman, 2012), so that later students can become athletes who are competent, literate, and enthusiastic (O'Neil \& Krause, 2016; Glotova \& Hastie, 2014). With SEM students are taught basic techniques, tactics, or strategies to play. Previous studies reported that the SEM curriculum can help students improve their 
knowledge and performance skills, as well as decision-making skills (Rocamora et al., 2019). Research of Lee et al., (2016) emphasized that the SEM curriculum makes students more active in learning physical education, even being able to make someone happy in doing all physical activities. Another study found that SEM is a widely used physical education curriculum model and has been associated with positive psychological outcomes among students, such as increased competence, affiliation, motivation, and enjoyment (Chu \& Zhang, 2018).

The two curriculum models between FEM and SEM both have a large impact on increasing participation in physical activity and students' enjoyment, but when referring to the mean value of the two groups, it shows that FEM has a greater mean value than SEM. This happens because between FEM and SEM have different learning characteristics and FEM is proven to cause students' physical activity to be much higher when participating in the learning process. In addition, it seems that students feel more happy and enjoy all the programs contained in the FEM, for example students are very enthusiastic when doing tabata training which is one form of exercise contained in the FEM program.

\section{CONCLUSION}

Based on the results and discussions that have been described previously, it can be concluded that the two models of physical education curriculum between FEM and SEM are proven in this study to be an important key in increasing participation in physical activity and students' enjoyment of sports. This research has had a major impact on the development of the physical education curriculum in Indonesia and provides information for lecturers at the university level about the importance of using FEM and SEM for students at the university level. However, this study still has limitations, namely the subjects used are relatively small from one study program at Universitas Suryakancana.

\section{ACKNOWLEDGEMENT}

Thank you to those who have contributed to this research, especially to the Universitas Suryakancana Cianjur.

\section{CONFLICT OF INTEREST}

All authors declare no conflict interest in this Future research needs to be done, such as adding subjects from several Departments of Physical Education, Health, and Recreation from different Universities in Indonesia or comparing other curriculum models such as TGM research.

\section{REFERENCES}

Araújo, R., Hastie, P., Lohse, K. R., Bessa, C., \& Mesquita, I. (2019). The long-term development of volleyball game play performance using Sport Education and the Step-Game-Approach model. European Physical Education Review, 25(2), 311-326. https://doi.org/10.1177/1356336X17730307

Ashadi, K., Andriana, L. M., \& Pramono, B. A. (2020). Pola aktivitas olahraga sebelum dan selama masa pandemi COVID-19 pada mahasiswa fakultas olahraga dan fakultas non-olahraga. Jurnal SPORTIF : Jurnal Penelitian Pembelajaran, 6(3), 713-728. https://doi.org/10.29407/js_unpgri.v6i3.14937

Bandura, C. T., \& Kavussanu, M. (2018). Authentic leadership in sport: Its relationship with athletes' enjoyment and commitment and the mediating role of autonomy and trust. International Journal of Sports Science \& Coaching, O(0), 1-10. https://doi.org/10.1177/1747954118768242

Bessa, C., Hastie, P., Rosado, A., \& Mesquita, I. (2021). Sport education and traditional teaching: Influence on students' empowerment and self-confidence in high school physical education classes. Sustainability (Switzerland), 13(2), 1-14. https://doi.org/10.3390/su13020578 
Bonavolontà, V., Cataldi, S., Maci, D., \& Fischetti, F. (2020). Physical activities and enjoyment during the lockdown: Effect of home-based supervised training among children and adolescents. Journal of Human Sport and Exercise, 15(4proc), S1338-S1343. https://doi.org/10.14198/jhse.2020.15.Proc4.31

Chu, T. L., \& Zhang, T. (2018). Motivational processes in Sport Education programs among high school students: A systematic review. European Physical Education Review, 24(3), 372-394. https://doi.org/10.1177/1356336X17751231

Deenihan, J. T, \& Macphail, A. (2013). A Preservice Teacher's Delivery of Sport Education: Influences, Difficulties and Continued Use, 166-185. https://doi.org/10.1123/jtpe.32.2.166

Deenihan, J. T., \& MacPhail, A. (2017). The influence of organizational socialization in preservice teachers' delivery of Sport Education. Journal of Teaching in Physical Education, 36(4), 477-484. https://doi.org/10.1123/jtpe.2016-0218

Dudley, D. A., Okely, A. D., Pearson, P., Caputi, P., \& Cotton, W. G. (2013). Decline in enjoyment of physical education among culturally and linguistically diverse youth. International Journal of Quantitative Research in Education, 1(4), 408. https://doi.org/10.1504/ijqre.2013.058308

Elliott, S., Drummond, M. J., Prichard, I., Eime, R., Drummond, C., \& Mason, R. (2021). Understanding the impact of COVID-19 on youth sport in Australia and consequences for future participation and retention. MC Public Health (2021) 21:448. https://doi.org/10.1186/s12889-021-10505-5

El-Sherif, J. L. (2014). Student Voice: Student Choice and Participation in Physical Education. Strategies: A Journal for Physical and Sport Educators, 27(5), 8-11. https://doi.org/10.1080/08924562.2014.938875

Farias, C., Valério, C., \& Mesquita, I. (2018). Sport Education as a Curriculum Approach to Student Learning of Invasion Games: Effects on Game Performance and Game Involvement. Journal of Sports Science and Medicine, 1(November 2017), 193-201.

Fu, Y., Gao, Z., Hannon, J., Shultz, B., Newton, M., \& Sibthorp, J. (2013). Influence of a health-related physical fitness model on students' physical activity, perceived competence, and enjoyment. Perceptual and Motor Skills, 117(3), 956-970. https://doi.org/10.2466/10.06.PMS.117x32z0

Gil-Arias, A., Harvey, S., Cárceles, A., Práxedes, A., \& Del Villar, F. (2017). Impact of a hybrid TGfUSport Education unit on student motivation in physical education. PLoS ONE, 12(6), 1-17. https://doi.org/10.1371/journal.pone.0179876

Glotova, O. N., \& Hastie, P. A. (2014). Learning to teach Sport Education in Russia: factors affecting model understanding and intentions to teach. Sport, Education and Society, 19(8), 1072-1088. https://doi.org/10.1080/13573322.2012.732567

Gråstén, A. (2016). Children's expectancy beliefs and subjective task values through two years of schoolbased program and associated links to physical education enjoyment and physical activity. Journal of Sport and Health Science, 5(4), 500-508. https://doi.org/10.1016/j.jshs.2015.12.005

Grasten, A., Timo, J., Jarmo, L., Anthony, W., \& Sami, Y.-P. (2012). Prediction of enjoyment in school physical education. Journal of Sports Science and Medicine, 11(2), 260-270.

Hastie, P. A., \& Wallhead, T. (2016). Models-based practice in physical education: The case for sport education. Journal of Teaching in Physical Education, 35(4), 390-399. https://doi.org/10.1123/jtpe.2016-0092

Hasyim, H., Ramadan, G., Dwiansyah Putra, D., Okilanda, A., Mulayana, N., Hadiana, O., ... Iskandar, D. (2020). Sport Education Model: Improving Student Motivation in Physical Education. International Journal of Psychosocial Rehabilitation, 24(8), 1421-1426. https://doi.org/10.37200/IJPR/V24I8/PR280155 
Innerd, A. L., Azevedo, L. B., \& Batterham, A. M. (2019). The effect of a curriculum-based physical activity intervention on accelerometer-assessed physical activity in schoolchildren: A non-randomised mixed methods controlled before-and-after study. PLoS ONE, 14(12), 1-17. https://doi.org/10.1371/journal.pone.0225997

IPAQ. (2005). Guidelines for Data Processing and Analysis of The International Physical Activity Questionnaire (IPAQ) Short and Long Forms.

Iserbyt, P., Ward, P., \& Martens, J. (2016). The influence of content knowledge on teaching and learning in Traditional and Sport Education contexts: an exploratory study. Physical Education and Sport Pedagogy, 21(5), 539-556. https://doi.org/10.1080/17408989.2015.1050662

Kirk, D. (2013). Educational Value and Models-Based Practice in Physical Education. Educational Philosophy and Theory, 45(9), 973-986. https://doi.org/10.1080/00131857.2013.785352

Lee, H. M. L., Oh, J., Baek, S., \& Kim, Y.-S. (2016). The Influence Of The Sport Education Model On An Adapted Physical Education Teacher' S Conceptions. Journal of Kinesiology and Wellness, 5(1994), $21-24$.

Lohbeck, A., Tietjens, M., \& Bund, A. (2016). Physical self-concept and physical activity enjoyment in elementary school children. Early Child Development and Care, 186(11), 1792-1801. https://doi.org/10.1080/03004430.2015.1132708

Mooney, A., Moncrieff, K., \& Hickey, C. (2018). Exploring pre-service teachers' experience of Sport Education as an approach to transition pedagogy. Physical Education and Sport Pedagogy, 23(6), 545558. https://doi.org/10.1080/17408989.2018.1485137

Mustafa, P. S. (2020). Kurikulum Pendidikan Jasmani, Olahraga, dan Kesehatan di Indonesia Abad 21. JARTIKA Jurnal Riset Teknologi dan Inovasi Pendidikan, 3(2), 422-438. https://doi.org/10.36765/jartika.v3i2.268

Mustafa, P. S. (2021). Problematika Rancangan Penilaian Pendidikan Jasmani, Olahraga, dan Kesehatan dalam Kurikulum 2013 pada Kelas XI SMA. Edumaspul: Jurnal Pendidikan, 5(1), 184-195. https://doi.org/10.33487/edumaspul.v5i1.947

Nugraha, P., Utama, M., S, A., \& Sulaiman, A. (2020). Survey Of Students Sport Activity During Covid-19 Pandemic. Jp.Jok (Jurnal Pendidikan Jasmani, Olahraga dan Kesehatan), 4(1), 11-24. https://doi.org/10.33503/jp.jok.v4i1.805

O’Neil, K., \& Krause, J. M. (2016). The Sport Education Model: A Track and Field Unit Application. Journal of Physical Education, Recreation \& Dance, 87(9), 14-20. https://doi.org/10.1080/07303084.2016.1226217

Perlman, D. (2012). The influence of the Sport Education Model on amotivated students' in-class physical activity. European Physical Education Review, 18(3), 335-345. https://doi.org/10.1177/1356336X12450795

Prasetyo, M. A. P., \& Winarno, M. E. (2017). Hubungan Antara Status Gizi dan Aktivitas Fisik Dengan Tingkat Kebugaran Jasmani Pada Siswa SMP. Jurnal Pendidikan Olahraga dan Kesehatan, 4(2), 516521.

Rakhmawati, D. (2017). Konselor Sekolah Abad 21: Tantangan dan Peluang. Jurnal Konseling GUSJIGANG, 3(1), 58-63.

Rocamora, I., González-Víllora, S., Fernández-Río, J., \& Arias-Palencia, N. M. (2019). Physical activity levels, game performance and friendship goals using two different pedagogical models: Sport Education and Direct Instruction. Physical Education and Sport Pedagogy, 24(1), 87-102. https://doi.org/10.1080/17408989.2018.1561839 
Romar, J.-E., Henriksson, J., Ketomäki, K., \& Hastie, P. (2016). Teachers' Learning Experiences with the Sport Education Model in Physical Education. Scandinavian Sport Studies Forum, 7(Published March 14, 2016), 1-26.

Setiawan, E., Patah, I. A., Jumareng, H., \& Kastrena, E. (2020). Model Model Pembelajaran dalam Pendidikan Jasmani. Bandung: Alfabeta.

Shimon, J. M., Johnson, T., Moorecroft, S., \& Bell, K. (2013). Fitness and Enjoyment Outcomes of a Physical Education Fitness Conditioning Curriculum |WSKW.org. Kinesiology \& Wellness in Journal of Kinesiology \& Wellness.

Silva, D. A. S., Chaput, J. P., \& Tremblay, M. S. (2019). Participation frequency in physical education classes and physical activity and sitting time in Brazilian adolescents. PLoS ONE, 14(3), 1-14. https://doi.org/10.1371/journal.pone.0213785

Sun, Z. (2016). The Advantage of Using Sport Education Instead of Traditional Approach in Physical Education, 6(2), 13-16. https://doi.org/10.9790/7388-0602031316

Thorburn, M. (2015). Theoretical constructs of well-being and their implications for education. British Educational Research Journal, 41(4), 650-665. https://doi.org/10.1002/berj.3169

Wallhead, T. L., Garn, A. C., \& Vidoni, C. (2013). Sport Education and social goals in physical education: relationships with enjoyment, relatedness, and leisure-time physical activity. Physical Education and Sport Pedagogy, 18(4), 427-441. https://doi.org/10.1080/17408989.2012.690377

Wallhead, T. L., Garn, A. C., \& Vidoni, C. (2014). Effect of a sport education program on motivation for physical education and leisure-time physical activity. Research Quarterly for Exercise and Sport, 85(4), 478-487. https://doi.org/10.1080/02701367.2014.961051

Ward, J. K., Hastie, P. A., Wadsworth, D. D., Foote, S., Brock, S. J., \& Hollett, N. (2017). A Sport Education Fitness Season's Impact on Students' Fitness Levels, Knowledge, and In-Class Physical Activity. Research Quarterly for Exercise and Sport, 88(3), 346-351. https://doi.org/10.1080/02701367.2017.1321100

Walton-Fisette, J. L., \& Sutherland, S. (2018). Moving forward with social justice education in physical education teacher education. Physical Education and Sport Pedagogy,23(5), 461-468. https://doi.org/10.1080/17408989.2018.1476476

Xiang, M. Q., Tan, X. M., Sun, J., Yang, H. Y., Zhao, X. P., Liu, L., .. Hu, M. (2020). Relationship of Physical Activity With Anxiety and Depression Symptoms in Chinese College Students During the COVID-19 Outbreak. Frontiers in Psychology, 11(November), 1-7. https://doi.org/10.3389/fpsyg.2020.582436 